QIJIS : Qudus International Journal of Islamic Studies

Volume 7, Number 1, 2019

DOI : $10.21043 /$ qijis.v7i1.4252

\title{
MUTUAL TRANSFORMATION IN THE EARLY HISTORIES OF CHRISTIANITY AND ISLAM
}

\author{
Izak Y. M. Lattu \\ Satya Wacana Christian University \\ lattu@staff.uksw.edu
}

\begin{abstract}
This article examines interreligious mutual relationships in the historical teachings of Christianity and Islam. Drawing on John $B$. Cobb, Jr's mutual transformation theory, the article argues that early Christian and Muslim scholars have learned from other traditions in developing their religious teachings. The article employs historical writings on the key figures and the early scholars of Christianity and Islam to comprehend patterns of mutual transformation in both religions. Based on documentary research, this article illustrates mutual contact and creative interaction with other religious communities in the history of Christianity and Islam. Both Christian and Muslim early philosophers touch upon classical Greek Philosophers and their written texts to develop intellectual traditions and teachings. Using Greek philsophy as pivotal point of encounter, Christian scholars also contributed to the developement of Islamic philosophy. As a result of the encounter, mutual transformation invites people to be involved in a deep dialogue and to be openhearted to learn from the teachings of other religious traditions.
\end{abstract}

Keywords: Mutual transformation, Philosophy, interreligious dialogue, Christianity, Islam 


\section{A. Introduction}

Mutual transformation is an approach toward the reciprocal relationships between religious traditions in the field of theology of religions today (Cobb, 1998; Cobb, 1999; Knitter 2002; Kayaoglu, 2015). Bearing the spirit of religious openness and acceptance towards truth in other religions, this approach becomes a response to religious attitudes toward other religions that tend to trap religious followers in exclusivism and lead to religious narrowmindedness. Mutual transformation opens avenue for religious followers to cross over and go deeper into the soil of religious others; so that one can come back with a broader understanding of the others. At this point, the essence of mutual transformation is the openness to listen and learn from others without ignoring the core characteristics of religious identity (Cobb, 1998).

In the field of religious studies, mutual transformation has become a response to three other attitudes towards other religions: exclusivism, inclusivism and pluralism. John Cobb, Jr.'s mutual transformation is acceptance, listening and learning from other religions (Cobb, 1999). Mutual transformation or acceptance goes beyond absolutism, because it rejects exclusivism or inclusivism and goes beyond relativism. The main argument of mutual transformation is being openhearted to other people without losing previous religious identity. He rejects religious attitude that focuses solely on similarity of religions and avoids differences because it will produce relativism. Focusing on similarity, people may reduce strong conviction of their own religions to simply embrace the resemblance and monotony of religious values (Cobb, 1999:95-100).

Religious transformation invites people to a universal salvation. Cobb insists that mutual transformation does not stop in peaceful co-existence, but continue to transform religious followers towards open attitude and ability to learn from teaching and wisdom of other religions without losing self-religious identity (Cobb and Griffin, 1976:14; Cobb, 1998:52). Cobb divides mutual 
transformation in two levels: a core area and an altered area (Cobb, 1999). The core area is the unchangeable vicinity within a religious identity, even when one lives among, listens to, and learns from other religions. Unlike the core area, the altered area is a transformable quarter in the realm of religious identity.

Many scholars have studied early history of Christianity and Islam (Fakhry, 1970; Berkhof and Enklaar, 1993; Nasr, 2006; Edwards 2010; Smarandache, 2018). In the same manner, plethora of scholar works have explored interreligious encounter in history of Christianity and Islam (Al-Faruqi, 1998; Penn, 2009; Winkler, 2010; Freely 2011). However, not many scholars study religious mutual transformation in the Greek philosophical reception on Arab World during the early encounter of Christianity and Islam when Muslim scholars developed the concept of Islamic philosophy. This article, therefore, argues that the openness to learn from other religions provides a foundation for further interreligious understanding, particularly in the history of Islam and Christianity. The mutual transformation opens avenue to learn from other faiths. This study explores John Cobb's mutual transformation and examines the transformation in the history of Christianity and Islam. The research also argues that mutual transformation has taken place in the history of Christianity since the time of Jesus, while to prove the existence of mutual transformation in Islam, this article deals with Al-Kindi, Al Farabi and Ibn Sina's experiences of quoting classical Greek philosophy in their works. The three scholars also serve as epitomes of exemplary in Christian-Muslim relationships. Therefore, the paper is more a historical study of Christian-Muslim relationships rather than a theological exploration.

\section{B. Mutual Transformation in the Early Christian Teachings}

Mutual transformation in the tradition of church is rooted in the history of Christianity. Here, I will focus on mutual transformation in two major issues: first, mutual transformation 
is a cultural transformation. In Jesus' or the early church fathers' lifetimes, Greek culture, Roman culture and Judaic culture were dominant. The influence of other traditions is central in the history of Christianity. Scholars like Ismail Raji al-Faruqi, for instance, have eloquently pointed out the influences in the early period Christianity (al-Faruqi, 1998:30). The footsteps of the influences have existed in New Testament documents and early church literatures. Second, Jesus Christ is the central figure of transformation in Christian Mutual Transformation. The Gospel of John points out that Jesus Christ is the Logos (Word) of God, who became human being (John 1:1). In Karl Barth's perspective, God revealed in the form of Son; God transformed into a human being to reconcile the broken relationship between God and humans. For Barth, God crosses the divine realm to encounter the mundaneness to establish reconciliation and peace. Therefore, the event of incarnation is the episode of transformation that leads to mutual transformation in Christian teaching (Barth, 2009:106-109).

Major parts of Christian teaching, in its establishment and development, had absorbed Greek philosophy as well as Greek and Roman cultures to develop Christian church' credo. Cobb, Jr. insists that Early Christian scholars had developed Christian teaching by incorporating Greek wisdom. The teaching transformed Greek philosophy and was transformed by Greek philosophy (Cobb Jr., 1997:52). The mutual encounter encouraged assimilation of much Greek philosophy in Christian theology (Cobb, 1998:6-7). In a similar way, Greek Christianity of the fourth century was rooted in Hellenism. In other words, Early Christian scholars absorbed Greek ideas to shape their religious teachings (Hatch, 1957:4-5).

In 334 Before Coming Era (BCE), Alexander the Great or Iskandar Zulkarnain, the king of the great city-state of Macedon, began to conquer the world. Alexander believed that the colonization has two main goals: for his own glory and the spreading of Hellenistic values. He endorsed the hegemony of Greek vernacular 
and civilization throughout his empire (Harding, 2003:14). As both a conqueror and missionary he was remarkably successful. From Aristotle, Alexander learned metaphysics and foundation of Greek philosophies (Berkhof and Enklaar, 1993:122). Not a philosopher himself, Alexander nevertheless sought to spread Greco-Roman culture to "other worlds." William Ramsay argues that when Alexander the Great founded the Alexandria he had planned that city to be the greatest municipality of Hellenistic civilization. He imposed Greek to be the Empire lingua franca. Having a strong spirit to introduce Hellenism throughout the world, Alexander claimed himself an apostle and missionary of classical Greek culture (Ramsay, 1995:12-13). The Hellenistic political atmosphere assisted early Christian scholars to shape Christian teachings in the Greek philosophy and distributed the teachings through the lingua franca. Hellenistic culture functioned as a great means for the rise of Christianity. Although emerged from the Galilean countryside and incorporated many ideas from its Jewish origins, Christianity moved quickly to Roman Empire cities where the urban communities gradually recognized and accepted the belief.

Christianity borrowed not only the language but also ideas of the late Hellenistic age: Stoic and Platonic (Meier, 2012:14). Exemplary form of how Platonic ideas influenced early Christian teaching, among others, is II Cor 4: 18, "the things that are seen are transient, but the things that are unseen are eternal." This text is almost pure Platonism. In addition, Norman Perrin and Dennis Duling insist that Stoicism also influenced the St. Paul's writings. The Stoic teaching claims that the divine reason, the logos, orders the world. This philosophy also believes that a seed of the logos dwelt within human beings who live peacefully in the world only by obeying the divine seed. Perrin and Dulling adds that Stoic style of argumentation and the habit of listing virtues influence of St. Paul theology (Roman 1:16) as well as other New Testament documents such as James 2:14 (Perrin and Duling, 1982:95). St. Paul's letter to the 
Christian people in Philippi, "For me to live is Christ...to die is gain" (Phil. 1:21), clearly reflects the employment of the Platonic ideas in early Christian writings. For St. Paul, the most significant and transformational spiritual reality is the new life in Christ. By reading the piece of his letter, one could argue that in St. Paul's mind Christ was the Spirit or lived in the Sprit or mediated the Sprit (Grant, 1962:2).

The evidence of Greek thought in St. Paul, the early Church fathers thoughts have represented the Greek influence in the teaching of Christianity. Church fathers lived and worked under Greco-Roman colonial power, therefore the influence is certainly existed in the posture of their arguments. As Frederick Grant notes:

St. Ambrose's De Officiis ministrorum is based upon Cicero's De Officiis, though Cicero was only half a stoic. Or take the conception of the Logos, the reason, mind, or word of God by which the universe was created, by which it is sustained, and which became incarnate in Jesus of Nazareth. Nevertheless, the basic concepts in Christian theology, from that day to this, were either derived from or influenced by Hellenic philosophers. For example, the conception of the nature and the person of Christ, set forth in the ecumenical creeds, is by no means the old Jewish prophetic or apocalyptic conception, but one, which has been molded under the influence of Greek Philosophy (Grant, 1962:22).

This quotation highlights a strong influence of Greek philosophers to today Christian teachings. Adolf Harnack argues that Christian teaching is the result of intertwinement of Greek philosophies and Gospel narratives (Harnack, 1923:73). Greek philosophical has strongly influenced the teachings of Tertullian, Clement of Alexandria, Origen, and many more early Christian scholars. The scholars employed Plato, Aristotle, and other Greek philosophers idea to frame Christian dogma. Among the Greco-Roman philosophies, Platonism was the biggest school of thought that influencing Christian dogma. Although the early Church rejected some ideas of the scholars that borrowed from Greek philosophers, the scholar legacy continued influence Christian dogma. For instance, the church pushed back Origen's idea on the Logos in 399 CE, but 
the idea remains strong in the Orthodox Church and other Eastern Churches (Berkhof and Enklaar, 1993:41-43). In summary, one may concludes that Christian scholars have recognized the influence of classical Greco-Roman thought upon the history of Christianity.

Developed from the womb of Jewish worldview, Jewish traditions and teachings played a major role in the rise of Christianity. John Cobb Jr., argues that Christianity is the blood-child of Judaism because from its beginning Christianity already included Judaic moral values and guidelines in Christian teachings (Amstrong, 1993:92). An unquestionable example of Christian employment of Jewish principles is recognition of the Jewish Scripture, the Hebrew Bible, by Christian community. During the canonization of Christian Bible, no early Christian scholars questioned the Hebrew Bible appropriation in Christian scripture. Disputation over many apocryphal books had divided Early Christian scholars into groups, and later churches, but most scholars agreed upon the acceptance of Hebrew Bible in the Christian sacred canon (McDonald 2011: 78 - 83). Christianity, if fact, has borrowed from teachings of many other sources to enrich Christian values and moral judgments.

Before the early fathers formulated Christian credo as the intertwinement of Christian understanding and Greek philosophy, Jesus' teaching, especially his parables, was rooted in Judaism. For instance, Jesus borrowed the Jewish conception of heaven and inserted a new meaning into the concept. He also employed existing Jewish moral principles and curved the guidelines with new applications. Indeed, Jesus himself was born into a Jewish family and grew up as a young Jewish. As a Jew, Jesus attended the Sabbatical worship regularly (Luke 4:31). The Gospel of Mark's author highlights Jesus Jewishness by emphasizing his preaching message in Galilee, "The right time has come, and the Kingdom of God is near" (Mark 1:15). The Kingdom of God is one of the primary concepts in Judaic teaching that Jesus employed to encapsulate his 
moral guidance. The practice of Jewish guidelines had lead towards victimization of early Christian community under Jewish law and Roman government: Christianity as a breakaway Jewish sect (Amstrong, 1993:91).

The above explanation has obviously shown the debt that Christianity owes to both Greek thought and Judaism as Jesus and early Christian scholars had quoted and employed the JudaicHebraic perspective in shaping the posture of Christian theology. Jesus and early Christian scholars' engagement with Judaic-Hebraic idea have clearly illustrated the idea of mutual transformation in Christian history. Christianity is not an isolated island, buta juncture of Judaic-Hebraic moral guidance and Hellenistic philosophies. This narrative leads toward a fundamental assumption that Christian thought is the result of historical encounters with other religious traditions and philosophies.

\section{Mutual Transformation in Early Muslim Experiences}

In the history of Islam, mutual transformation has rooted in the life of Prophet Mohammad (Peace Be Upon Him) and the works of Islamic classical scholars and philosophers, such as Ibn Sina, Al-Farabi, Al-Kindi and many more. Prophet Mohammad's sayings and practices (Hadith and Sunnah of the Prophet) have been the anchor of sacred teachings in the course of Islamic history. Aside from the narrative of peace in the Prophet Mohammad's life, Muslim scholars and philosopher are central in development of Islamic jurisprudence (shariah) and teaching significantly (aqidah) (Nasr, 1964:10-11).

The life of the Prophet Mohammad itself is a model of mutual transformation in Islam. His life is an example of mutual understanding, respect, and dialogue: the heart of mutual transformation. Prophet's interaction with Christians, before and after his prophetic calling, reflects his openness to respect the truth in other religions. His dialogue with Waraqah ibn Nawfal, underlines Proph- 
et Mohammad willingness to listen sympathetically to different voice. Husayn Haykal says:

One day Muhammad went to the Ka'bah for circumambulation. He was met by Waraqah ibn Nawfal, who asked him about himself. Muhammad related the events as they had happened. When he finished, Waraqah said, "By Him who dominates my soul I swear that you are the Prophet of this nation. The great spirit that has come to Moses has now come to you. You will be denied and you will be hurt. You will be abused and you will be pursued. If I should ever live to see that day I shall surely help the cause of God. God knows that I will." Waraqah then approached Muhammad, kissed his forehead and went away. Muhammad realized the faithfulness of Waraqah, and at the same time felt the burden weighing on his shoulder (Haykal, 1982:78).

Waraqah, who was a Christian, addressed Mohammad's prophethood using the teachings of Judaism (the great spirit of Moses). Prophet Mohammad sympathetic dialogue with Waraqah indicates two important mutual transformation moments: first, Prophet Mohammad reflects the centrality of listening to people from different religious traditions. Prophet Mohammad humbleness and openness toward the narrative of other religions had encapsulated dialogue centrality in the interreligious encounter. Second, when Prophet Mohammad listened sympathetically to Waraqah confession, the Prophet recognized the truth in other beliefs. Prophet Mohammad positive response to Waraqah symbolic action (kissing the Prophet on the forehead) emphasized the Prophet humbleness to appreciate truth behind Waraqah sayings and ritual practices.

Second event of religious transformation in the early Islamic history is first hijrah, migration, to Abbesyah (Ethiopia). When Muslims decided to escape from Mecca to Abbesyah, the early Muslims believed that the Christian government and people of Abbesyah would save the Muslims as the Abbesynians believed in revelation and the Word of God as well. As "ahlul kitab," the people of the book, Ethiopian Christians believed in the revelation, the oneness of God, and the everlasting life (Haykal, 1982:79). The belief 
system is the pivotal common ground for Muslim and people of the book. The common ground served as social solidarity that played behind the reason of the first Muslim hijrah and the support from the Ethiopian Christians.

The third transformative lesson from the life of the Prophet Mohammad is his conversation with the Christians from Najran. In the conversation between the Prophet and the Christian delegation, Muhammad Husayn Haekal writes:

We believe in what has been revealed to Moses, to Jesus, as well as in all the revelations which the prophets have received from their Lord. We do not differentiate between them. And we have submitted ourselves to God. Muhammad criticized both Jews and Christians in very strong terms for their compromise of the monotheistic faith that God is one, for tempering with the words of God in their scriptures, and for interpreting them in ways violating the understanding of the prophets whose prophethood they themselves acknowledge (Haykal, 1982:195).

From Haykal's explanation of the conversation, it is clear that Prophet Mohammad agreed with shared narratives in Abrahamic religions. The shared narratives functioned as the main platform of Prophet Mohammad conversation with the Christian delegation. In the conversation, Prophet Mohammad also highlighted differences between Islam, Christianity and Judaism. By acknowledging the convergence and divergence of religious truth, Prophet Mohammad experienced a transformative moment. As Cobb frames the concept of mutual transformation as ability to learn from both divergence and convergence. In the transformative point of view, one should learn from a meeting point and disparity (Cobb, Jr., 1995:106). Prophet Mohammad has posted the exemplary of openness to recognize convergences and divergences of religious teachings.

The fourth transformative message from Prophet Mohammad's life is his invitation for all groups in the city of Medina to come into a consensus: Medina Consensus (Mistaqal Madina). The 
47 articles of the Medina Consensus is the maxim for the relationship between religious groups and the state Islam. For example, articles $1,16,25$, and 37 play as the primary reason behind religious acceptance in Islamic perspective. Those articles says:

Article 1: They are a single community (ummah) distinct from (other) people.

Article 16: Whoever of the Jews follows us has the (same) help and support (nasr, iswah) (as the believers), so long as they are no wronged (by him) and he does not help (others) against them.

Article 25: The Jews of Banu 'Awf are a community (ummah) along with the believers. To the Jews their religion (din) and to the Muslim their religion. (This applies) both to their clients and to themselves, with the exception of anyone who has done wrong or acted treacherously; he brings evil on himself and on his household. (Article 26-31 repeat this rule for six other Jewish tribes of Madina at the time).

Article 37: It is for the Jews to bear their expenses and for the Muslims to bear their expenses. Between them (that is to one another) there is help (nasr) against whoever wars against the people of this document. A man is not guilty of treachery through (the act of) his confederate. There is help for the wronged (Nasr, 1989:141).

Prophet Mohammad has established a pattern of peaceful religious relationship in Islam. The Medina Consensus clearly mentioned religious understanding among people who lived in the same state. Article 25 explicitly pointed out mutual relationship and respect: "To Jews their religion and to Muslims their religion." Each party has a belief; as a community it doesn't lead to conflict but understanding instead.

\section{Christian-Muslim Mutual Transformation in Islamic Philo- sophy}

Majid Fakhry opens his book History of Islamic Philosophy 
by claiming: "Islamic philosophy is the product of a complex intellectual process in which Syrians, Arabs, Persians, Turks, Berbers, and others took an active part" (Fakhry, 1970:1). In Fakhry's mind, Greek thought had an enormous impact on the Muslim way of thinking. The varying degrees of allegiance to Greek philosophy and logic produce not only the diverse theological schools of thought, but, for Fakhry, it also generated Hellenic modern of ideas, which we shall designate as the Islamic philosophy school (Fakhry, 1970:6-7). Greek philosophy has penetrated Islamic philosophy through the translation of the classical Greek works under the rule of al-Mansur (754-75). Al-Mansur initiated the translation of Aristotle's On Logic, Ptolemy's Almagest, Necomachus' Arithmetic, Euclid's The Element, and many more (Freely, 2011:28). During al-Mansur time, Hellenic ideas began to spread and became the foundation of knowledge development in Arabic world.

As the result of Hellenic domination in Arab world during Roman Empire, the existing Greek thoughts influence the formation of Islamic philosophy. Seyyed Hossein Nasr argues that there is a strong reception of Greek culture, thought, and tradition in Islamic philosophy through the work of scholars such as Ibn Arabi whom scholars called "Plato in his day" and Al-Kindi who accepted the truth on Greek Philosophy to develop his Muslim philosophy (Nasr 2006: 42 - 44). John Esposito supports Nasr argumentation by emphasizing the transformations in multidimensional milieus: cultural, architectural, astronomical, and philosophicaltheological (Esposito, 1999:90-93). Since Muslims have encountered Greco-Roman, Jewish, and Christian thoughts and cultures, the cultural transformation also happened throughout the happenstance (Esposito, 1999:96). Using the same argument, Mulyadi Kartanegara, an Indonesian Muslim scholar, claims that the great encounter of Muslims with other religions and cultures took place in philosophy. He argues that Al-Kindi was able to open his mind to learn and absorb Greek philosophy because Christian 
scholars, who lived and served under the Islamic society of his time, nurtured Al-Kindi' scholarship (Kartanegara, 2002:67). Al-Kindi's ability to learn from Greek philosophy had curved the first Muslim philosopher manner to shape the Islamic philosophy that served as the foundation for all Islamic Philosophy (Freely, 2011:48). Ibn alNadim listed 242 works by Al-Kindi from philosophy to astrology. In his book On First Philosophy, Al-Kindi acknowledges his debt to the Greek philosophical works that influenced his search for truth (Freely, 2011:49).

As part of empire culture, Greek philosophy came across Islamic territory by being embedded in the Greco-Roman conquest mission (Butterworth and Kessel, 1994:73). Greek culture and philosophy have strongly influenced the culture and philosophy of the Roman colonies especially in the city of Alexandria. Alexander the Great has planned this particular city to be the center of to spread the Hellenistic state of mind throughout the empire (Rippin, 1999:114). In his attempt to conquer the colony, Alexander mixed Hellenic culture with that of Parsi. Alexander performed a good example of cultural syncretism when he married the daughter of King Darius. The Great Emperor also arranged a balance of the cultures, as he arranged the composition of the demography of urban areas under his empire (Nasr and Leaman, 1996:92).

After the death of Alexander the Great, his kingdom fell apart, but his idea of the Hellenic movement and mission remains influencing the culture and worldview of people in the former Greco-Roman colonies. Alexandria served as the center of Hellenic tradition as well as a place where Greco-Roman and Eastern thought mutually encountered (Edwards, 1973:125). Later, Alexandria became the center for many branches of study, such as mathematics, art, astronomy, and philosophy. Alexandria produced a number of Neo-Platonic philosophers including Plotinus, Porphyry and Lamblicus. In this famous city, major Christian, Jewish, or other philosophers were born (Nasr and Leaman, 1996:46). 
Although Alexander's great kingdom ended, the position of Alexandria as the center of Hellenic tradition and culture remained strong until its fall to the army of Ibn Al-As in November 641 (Green 2007: 60). When Muslim army conquered Alexandria, a significant number of Christian philosophers moved to Antioch, Nisibis, Edessa and other cities that functioned as centers for Hellenic studies in the Near East (Nasr and Leaman, 1996:47). Nonetheless, Muslim conquerors provided freedom and opportunity for philosophers and scholars in Edessa, Nisibis, Antioch, Harran and Jundishapur who worked under Muslim power to develop thinking system and nurtured young Muslim scholars who searched for knowledge and truth. In this era, Jacob from Edessa experienced freedom of religion to spread Christian theology among the Syrian-speaking people. Under this period, in Antioch, Al-Farabi enjoyed scholarship and of Christians scholars such as Yuhanna bin Hailan and Abu bisr Matta bin Yunus (Fakhry, 1970:126).

Mutual social and academic engagements of interreligious scholars reflects freedom of religious life under Islamic power. Dietmar Winkler claims that the intimate relationship between Syrian-Christian scholars and the Islamic court highligted strong relationship between Christians and Muslims in the early period of Islam (Winkler, 2010). Winkler argues:

...Syriac Christians in both empires lived in suspicion and fear until the coming of Islam, which in this context was seen to them as liberation. "the triumph of the people of Ishmael is a fact from God" says the $7^{\text {th }}$ century Cronica minora (Cronica minora. Ed. I. Guidi. (textus CSCO 1 Syr. 1, versio CSCO 2 syr 2), :ouvain 1960, syr. 38, lat. 31.) The same feeling is expressed by Michael the Syrian, who sees the hand of God behind (Chronique de Michel le Syrien Patriarche Jacobite d'Antioche (1166-1199). Ed. Jean-Baptiste Chabot. Tome II. Paris 1901, 32) In a letter of Ishoyahw III it is said: "Not only they do not attack Christian religion, but they respect our faith and honor our clergy and saints and support our churches and monasteries". The chronical of Seert goes further in its chapter on the apparition of the Arabs: "May God strengthen it and do for it triumph (Winkler, 2010:7). 
Winkler adds that for the early centuries of Islamic power, the caliphs employed a big number of Christian scholars to serve the sultanate. Under the Abasyiad period, Christian intellectuals served as medical doctors, engineers, philosophers, and so on. During caliphs travels across the sultane, the caliphs stopped by to enjoy Christian monasteries along the journey (Winkler, 2010:8). This direct contact create awarness of other religious knolwledge and existence.

Christian scholars enjoyed the freedom of intellectual exercise under the Muslim Caliphate. Monophysite monastery in Northern Syria continued Christian theological studies without any pressure from Muslim government. For example, Severus Sebokht, an outstanding Christian theologian, at the time, who had written commentaries on hermeneutics and Aristotle's rhetoric as well as his famous Syllogism Analytica Priora (Rippin, 1999:6570). Sebokht's pupil, Athanasius of Balad, later the Patriarch of Jacobite church, continued his work to translate classical Greek manuscripts into Arabic. Athanasius translated Prior Analystic and chronological succession from Posterior Analytics to the Sophistical Refutations (Watt 2010:37). In the course of Christian theology, Athanasius of Balad produced an encyclical criticized Christians presence in pagan festivals and consumed meals that offered to pagan gods (Penn 2009:235 - 257). During the Abbasyiah period, Baghdad played central role as the most prominent scholarly city where philosophy and science developed in the classical Arab time. The Nestorian-Christian scholars' presence in Baghdad served to bridge Greek culture and Arab/Persian world. The Nestorians taught and transformed Greek culture, thought, and tradition from Jundishapur into Baghdad schools. Through this close relationship, an intimate political engagement existed between Persia and the Abbasiyah Caliphate. Under the Abbasiyan power, Christian scholars translated Greek classical pieces into Arabic language (Nasr and Leaman, 1996:89-90). 
Muslim rulers of this era provided ample intellectual room for Christian scholars to continue the expertise that also benefited the development of Islamic scholarships. Through translations in the city of Alexandria, Greek philosophy, particularly Plato and Aristotle's thought, was available and accessible to Muslim scholars (Nasr and Leaman, 1996:92). Therefore, some famous scholars such as Al-Kindi, al-Farabi, Ibn Sina (Avicenna), Ibn Rush (Averroes), and Ibu Thufail had become the greatest thinkers in Islamic philosophy by consuming the translations of Greek philosophy. Indeed, world academia has recognized the Muslim scholars as part of greatest scholars in human history due to their openness and willingness to learn from other traditions (Nasr and Leaman, 1996:165-247).

The introduction and existence of Greek philosophy in the Islamic world have influenced the religious culture and knowledge as well as created dissension among Muslim scholars. Al-Ghazali for instance employed Greek philosophy to defend Islamic teaching against the heresy (Nasr and Leaman, 1996: 173). Yet Al-Kindi, the first genuine philosopher to write in Arabic, used the philosophy to engage Islam with the truth from other religions. For instance, Al-Kindi claimes,

We should not be ashamed to acknowledge truth and to assimilate if from whatever sources it comes to us, even if former generation and foreign peoples bring it to us. For him who seeks the truth there is nothing of higher value than truth; it never cheapens or debases him who reaches for it but ennobles and honors him (Amstrong, 1993:173-174).

In Al-Kindi's perspective, the core of philosophy is the knowledge about material in reality according to the human state of mind. Analogically, if philosophy is an art, it is the higher art of human beings because philosophy tries to gain truth theoretically and to attain the truth act practically. Also, philosophy strives to discuss virtue and how to cultivate it (Nasr, 1991:411). Religion and philosophy in Al-Kindi's mind are twofold. The argument rooted in Al-Kindi reading on the metaphysics of Aristotle and the 
Aristotelian theology of an unknown Neo-Platonic author (Walzer, 1962:2) as well as Neo-Platonic texts from Plotinus and Porphyry that translated into Arabic by Abu Bisr Matta. The translation project under Islamic ruler circulated the texts to the Arabic world through the city of Alexandria (Nasr and Leaman, 1996:95). Greek philosophers writings, especially that of Aristotle, has contributed to the development of knowledge in Arab world.

Aristotle idea functioned as the basic reading for classical scholar of Islam and served as the foundation of Islamic philosophy. Enthused by Plato's Republic, Al-Farabi published his first Muslim political treatise. Al-Farabi also paraphrased Aristotelian logic and applied it into Islamic perspective and reason (Fakhry, 2002:2021). In addition, another great Islamic scholar, Ibn Sina, employed Aristotle's philosophy to develop his own Muslim philosophy, The Cure. Aristotelian logic influenced Ibn Sina's argument of the relationship between soul and knowledge (McGinnis and Reisman, 2007:153). Although rooted in Aristotelian logic, Ibn Sina's philosophy employed the logic under the authority of Islamic knowledge that centered on Quran (Harrison, 2011). Islamic philosophy, in this perspective, is not solely rooted in Greek philosophy because the philosophy enjoyed dialectical relationship between Quranic teaching and Greek thought.

When Al-Farabi and Ibn Sina scrutinized the Neo-Platonic state of mind, the two scholars found the answers to some critical questions that arose from consistent study of Islamic teaching. In fact, they faced some crucial problems when both of them tried to explain the plurality of unity to argue that God is the creator. God creates plurality and maintains the plurality as the richness of human being life. Nonetheless, further questions arose of how to explain it in human history (McGinnis and Reisman, 2007:23). Here Neo-Platonism is helpful since Neo-Platonic philosophy focuses on the unity and transcendence of God (Kartanegara, 2002:14-32). As a consequence, it matches the Quranic teaching about the unique- 
ness of God (QS 42:11).

In summary, learning from the historical encounter and reception of Greek philosophy by Muslim scholars, one may concludes, using the lens of mutual transformation, that influence of Greek philosophy on Arabic world has contributed to the development of early Islamic philosophy. Indeed, Islamic philosophy has an impact on religious thought of many Islamic leaders and scholars. It offered a creative way to present Islamic principles and ideas in fields of Islamic theology and jurisprudence. Evidence of this creative presentation could be founded in the writings of Muslim intellectuals, mentioned above, as well as in the works of Abu Hamid al-Ghazali (d. 1111), Ibn Rushd (d. 1198), Ibn Arabi (d. 1240) and Mulla Sadra (d. 1640) from the early to modern periods. By looking at the philosophical discourse in the history of Islam, one might conclude that mutual transformation and creative acceptance have already existed in Islam since the early Muslim philosophers time.

\section{E. Conclusion}

Mutual transformation has taken place in the history of Christianity and Islamic thought. The histories of Christianity and Islam have clearly described the encounter between JudeoHebraic philosophy and that of Christianity as well as Islam. Christian philosophers such as St. Paul employed the structure of Greek philosophy to explain his theology. In Islamic history, Islamic scholars such as Al-Kindi, Al Farabi, and Ibn Sina adopted the logic of Platonic and Aristotelian philosophies to formulate Islamic philosophy. At this stage, mutual transformation has enriched religious understanding and broaden a positive and mutual perception towards other religions. Islamic and Christian histories teach that their followers as well as scholars of religious studies that both Christians and Muslims have practiced mutual transformation. Therefore, essentially, mutual transformation is not 
something new for Christians and Muslims. Mutual transformation is an old wine in a new bottle. It is not a new concept because early Christian and Muslim prominent figures had practiced the mutual transformation in their lifetimes.

In the Christian tradition, Greek ways of thought occupied New Testament. The authors of the New Testament clearly followed the Greek state of mind. The life of the Prophet Mohammad himself is the pattern for mutual transformation. Besides the life of the Prophet, Islamic philosophers such as Al-Kindi, Al-Farabi, Ibn Sina, etc., had employed classical Greek philosophy to explore and shape the Islamic philosophy. The Islamic philosophers have placed Greek philosophy and Islamic teaching, based on the Quran, in a dialectical relationship. Instead of receiving Greek philosophy as it is, the Muslim philosophers analyzed and used it in accordance with the Quran.

Mutual transformation goes beyond religious pluralism because it invites people to be involved in a deep dialogue and to be openhearted to learn from the teachings of other religious traditions. Mutual transformation has brought new hope to religious relations. In mutual transformation, religious adherents also have a great chance to understand and interact deeply with other religious people. Finally, according to this religious principle every religious group has its own salvation and truth by which one may learn from the differences and similarities of other religions.

\section{References:}

Al-Faruqi, I. R. (1998). Islam and Other Faiths. Ed. Ataullah Siddiqui. Leicester: Islamic Foundation.

Amstrong, K. (1993). The History of God. New York: Ballantine Books. 
Butterworth, C. E., and B. A. Kessel. (1994). The Introduction of Arab Philosophy into European. New York: E.J.Brill.

Barth, K. (2009). Church Dogmatics I.1. The Doctrine of the Word of God, trans. G. W. Bromingley, et al. New York: T\&T Clark.

Berkhof, H and I.H. Enklaar. (1993). Sejarah Gereja. [The History of the Church]. Jakarta: BPK Gunung Mulia.

Cobb, J. B., Jr. (1999). Transforming Christianity and the World: A Way beyond Absolutism and Relativism. Manchester: The Manchester University Press.

(1998). Beyond Dialogue: Toward a Mutual Transformation of Christianity and $B u d d h$ is $m$. Philadephia: Wipf and Stock Publishers. and David Ray Griffin. (1976.) Process Theology: An Introductory Exposition. Philadelphia:

The Westminster Press.

Craig, W. L. (2000). “No Other Name: A Middle Knowledge Perpective on the Exclusivity of Salvation through Christ," in Philip L. Quinn and Kevin Meeker, The Philosophical Challenge of Religious Divirsity. New York Oxford: Oxford University Press.

Coward, H. (1995). Pluralisme: Tantangan Bagi Agama-Agama. (Pluralism: The Challenge for Religions) trans. into Indonesian by Kanisius' Team. Yogyakarta: Kanisius.

Edwards, P. (ed.). (1973). The Encyclopedia of Philosophy. New York: Macmillan Publishing Co., Inc. \& The Free Press.

Edwards, M. J. (2010). "Early Christinity and Philosophy," in The Routledge Companion to Early Christian Thought, Bingham, Jeffrey, D (ed). Abingdong, Oxon: Routledge.

Esposito, J. L. (ed.). (1999). The Oxfort History of Islam. New York: Oxford University Press.

Freely, J. (2011). Light from the East: How the Science of Medieval Islam Helped to Shape the Western World. London and New 
York: I.B. Tauris.

Fakhry, M. (1970). A History of Islamic Philosophy. New York and London: Columbia University Press.

(2002). Al-Farabi, Founder of Islamic Neoplatonism: His Life, Works, and Influence. Oxford: Oneworld.

Grant, F. C. (1962). Roman Hellenism and The New Testament. New York: Charles Scriber's Sons.

Green, P. (2007). The Hellinistic Age. New York: Random House Publisher.

Goddard, H. (2001). A History ofChristian-Muslim Relations. Chicago: New Amsterdam Book.

Harrison, V.S. (2011). "Embodied Values and Christian-Muslim Dialogue: "Examplar Reasoning" As a Model for Interreligious Conversations," Studies in Interreligious Dialogue 21 (1) : 20 - 35 .

Haykal, M. H. (1982). The Life of Muhammad. Translated by Ismai'l Ragi A. al Faruqi. Lagos: Academy Press.

Harding, M. (2003). Early Christian Life and Thought in Social Context. London: T\&T Clark International.

Harnack, A. (1923). The Mission and Expansion of Christianity in the First Three Centuries. New York: J.C. Hinrichs.

Hatch, E. (1957). The Influence of Greek Ideas of Christianity. New York: Harper and Brother Publisher.

Hick, J. (1982). God Has Many Names. Philadelphia: The Westminster Press.

Hidayat, K. and A. A.F Gaud. (1998). Passing Over: Melampaui Batas Agama. [Passing Over: Crossing Religious Borders]. Jakarta: Gramedia dan Yayasan Paramadina.

Kartanegara, M. (2002). Trilogi Metafisis: Tuhan, Alam, dan Manusia. [Trilogy of Metaphisis: God, Universe and the Human Being]. Jakarta: UIN Jakarta. 
Kayaoglu, T. (2015). "Explaining Interfaith Dialogue in Muslim World," Politics and Religion 8 (2) : 1 - 27.

Knitter, P. (2002). Introducing Theologies of Religions. Maryknoll, NY: Orbis Books.

.(1995). One Earth Many Religions. Maryknoll, NY: Orbis Books.

McDonald, L. M. (2011). The Biblical Canon: Its Origin, Transmission, and Authority. Grand Rapids, Baker Academy.

McGinnis, J., and D. C. Reisman. (2007).Classical Arabic Philosophy: An Anthology of Sources. Indianapolis and Cambridge: Hackket Publishing Company.

Meier, C. (2012). A Culture of Freedom: Ancient Greece and the Origins of Europe. $\quad$ Oxford: Oxford University Press.

Nasr, S. H. (1964). Three Muslim Sages: Avicenna, Suhrawardi, Ibn Arabi. Cambridge, Massachusetts: Harvard University Press.

(1991). Islamic Sprituality: Manifestations. London: World Spirituality.

and Oliver Leaman. (1996). History of Islamic Philosophy Part I. London: NewYork: Routledge.

. (2006). Islamic Philosophy from Its Origin to the Present: Philosophy in the Land of Prophecy. Albany, NY: State University of New York.

Oklolm, D. L. and T. R. Phillips .(1995). On Salvation in a Pluralistic World. Grand Rapids. MI: Zondervan Publishing House.

Penn, M. P. (2009). "Monks, Manuscripts, and Muslims: Syriac Textual Changes in Reaction to the Rise of Islam," Huyoge: Journal of Syriac Studies 12 : 235 - 257.

Perrin, N. and D. C. Duling. (1982). The New Testament Introduction: Proclamation and Parenesis, Myth and History. New York: Harcourt Brace Jovanovich Publishers. 
Pinnock, C. H. (1995). "An Inclusivist View." in Dennis L. Oklolm and Timothy R. Phillips, On Salvation in a Pluralistic World. Grand Rapids, MI: Zondervan Publishing House.

Quinn, P. L. and K. Meeker. (2000). The Philosophical Challenge of Religious Diversity. $\quad$ New York Oxford: Oxford University Press.

Ramsay, W. H. (1995). The Layman's Guide to the New Testament. Atlanta: John Knox Press.

Rippin, A. (1999). Muslim: Their Religious Beliefs and Practices, Volume 1: The Formative Period. London;New York: Routledge.

Siddiqui, A. (1997). Christian-Muslim Dialogue in the Twentieth Century. London: Macmillan Press.

Smarandache, B. C. (2018). "The Hanbali Emigration of 551 - 569 AH/1156 - 1173 AD in The Context of Legal Discourse on Muslim under Non-Muslim Rule," Muslim World 108 (3) : $528-547$.

Sukidi. (2001). Teologi Inklusif Cak Nur (Inclusive Theology by Cak Nur ). Jakarta: Penerbit Buku Kompas.

Shihab, A. (1997). Islam Inklusif: Menuju Sikap Terbuka dalam Beragama. (Inclusive Islam: Toward an Open Religious Attitude) Bandung: Mizan dan ANTV.

Tillich, P. (1995). "The Future of Religions." in Harold Crouch, Pluralisme: Tantangan Bagi Agama-Agama. (Pluralism: the Challenge for Religions). Yogyakarta; Kanisius.

Walzer, R. (1962). Greek into Arabic: Essay on Islamic Philosophy. Oxford: Bruno Cassirer.

Watt, J. W. (2010). "Commentary and Translation in Syriac Aristotelian Scholarship: Sergious to Baghdad," Journal for Late Antique Religion and Culture 4 : 28 - 42.

Winkler, D. (2010).Syriac Churches Encounter Islam: PastExperiences and Future Perspectives. New Jersey: Gorgias Press. 
